\title{
HAEMATOLOGICAL BIOMARKERS IN DIFFERENT EXPERIMENTAL INTOXICATIONS IN PERCH
}

\author{
Maria Cristina Ponepal ${ }^{1,} *$, Alina Păunescu ${ }^{1}$ \\ ${ }^{1}$ University of Pitesti, Faculty of Sciences, Physical Education and Informatics, \\ str.Târgu din Vale, Piteşti, Argeş, Romania
}

\begin{abstract}
Haematological parameters reflect the condition of fish much faster than determining other parameters because they change extremely quickly as environmental conditions change, which is why they are widely used to describe the health of fish. Haematological and biochemical parameters can be used as standard laboratory tests to determine the effects of metabolic disorders caused by the action of xenobiotics. The purpose of this paper is to investigate changes in haematological parameters (erythrocytes, leukocytes, blood glucose levels) in perch Perca fluviatilis Linnaeus, 1758 in experimental intoxications with phenols (0.01 and $0.001 \mathrm{mg} / \mathrm{l})$, ammonia $(0.01$ and $0.001 \mathrm{mg} / \mathrm{l})$, some pesticides (Talstar One, Tilt 250 EC, Roundup ${ }^{\circledR}$ - in concentrations of 0.01 and $0.001 \mathrm{ml} / \mathrm{l}$ water) and two heavy metals (Cu and $\mathrm{Pb}$, in a concentration of 0.01 and $0.001 \mathrm{mg} / \mathrm{l}$ ). The tested substances produced changes of the mentioned parameters, the intoxications being followed, in most cases by the decrease of the average number of erythrocytes and the change of the glycaemic level.
\end{abstract}

Keywords: ammonia, blood glucose levels, erythrhrocytes, heavy metals, perch, pesticides, phenol.

\section{INTRODUCTION}

Toxic metals interfere with the normal metabolic functions of the essential elements. The catalyzed formation of metals by oxygen free radicals is involved in the production of many pathological changes, including mutagenesis, carcinogenesis and aging (Deplege and Rainbow, 1990). The main concern with lead is its ability to bioaccumulate in fish tissues, thus reducing the safety of human food, especially protein sources. Lead causes premature red blood cell death and inhibits hemoglobin formation by inhibiting $\delta$-amino levulinic acid dehydrase; the result of these changes is the appearance of anemia in case of exposure to high concentrations of lead, respectively compensatory effect of erythropoiesis at low concentrations (Hodson, 1976; Hodson et al., 1978). Fish exposed to high levels of lead have a number of effects, including degeneration and muscle and neurological destruction, growth inhibition, mortality, reproductive problems and paralysis (Eisler, 1988). Copper is an essential element for living organisms, participating as a cofactor in a large number of enzyme systems, but in high concentrations it becomes toxic. In the aquatic environment it is very toxic, having strong effects on fish, invertebrates and amphibians (Horne and Dunson, 1995).

http://www.natsci.upit.ro

* Corresponding author, E-mail address: ponepal_maria@yahoo.com 
Among the pesticides, we followed the effect of three products, belonging to the three main categories: insecticides, fungicides and herbicides. Talstar One (active substance bifentrin 7.9\%), belongs to the family of pyrethroid pesticides; is an insecticide-acaricide with a broad spectrum of control. Bifentrin is a contact insecticide that is part of the third generation of pyrethroid insecticides characterized by a strong persistence in the environment and an intense insecticidal action (Mokry şi Hoagland, 1989). Tilt $250 \mathrm{EC}$ is a local systemic fungicide, with preventive and curative action on a large number of pathogenic fungi, having as active substance propiconazole, in an amount of $250 \mathrm{~g} / \mathrm{l}$ - belongs to the group of triazole fungicides, introduced since the ' $80 \mathrm{~s}$ and belongs to the fourth class of toxicity. Propiconazole is frequently detected in aquatic ecosystems due to its increased persistence (Castillo et al., 2000). Roundup (glyphosate $360 \mathrm{~g} / \mathrm{l}$ ) is a totally non-selective, systemic, post-emergent herbicide that perfectly controls all annual and perennial weed species. Pure glyphosate (technical) is non-toxic to fish and slightly toxic to aquatic invertebrates. For example, 96-hour LC50 is $120 \mathrm{mg} / 1$ for Lepomis macrochirus, $86 \mathrm{mg} / \mathrm{l}$ for Oncorhynchus mykiss (US EPA, 1992).

Quite little is known about how phenols act on the body of fish. All that is known is that they are nerve toxic and that the symptoms of intoxication are similar to those produced by asphyxia. The toxicity limits given in the literature are extremely different: for fish they are between 5 and $60 \mathrm{mg} /$ 1 phenol. Rainbow trout (Salmo gairdneri) dies at $7.3 \mathrm{mg} / 1$ phenol in 2 hours, and at $6.5 \mathrm{mg} / 1$ in 12 hours; at these phenol concentrations a rapid damage to the gills and severe pathology of other tissues was observed (Mitrovic and colab., 1968, cited from Marinescu, 1972).

In its natural state, ammonia is found in small quantities, in the terrestrial atmosphere, in the water of rivers or seas; the ammonia concentration varies between 0.016 and $13.8 \mathrm{mg} / \mathrm{l}$. Ammonia enters the water through the gill epithelium of fish and from there into the blood, exerting a harmful action on the nervous system. At high concentrations there is even a destruction of the gill tissue, having a hemolytic action. Knepp and Arkin (1973), as well as Colt and Tchohanoglous (1976) - cited from Marinescu, 2000 - reported 96 h LC50 for Ictalurus punctatus species of $3.8 \mathrm{mg} / \mathrm{l}$ non-ionized ammonia, respectively $37.5 \mathrm{mg} / \mathrm{l}$ total ammonia.

The perch has a long history as a "sentinel species" in human-polluted waters (Balk et al., 1996; Sandström and colab., 2005; Hansson et colab., 2006; Hansson et al., 2009 - cited from din Hansson et al., 2014). Among the species belonging to the family Percidae, Perca fluviatilis has been identified as a potential candidate for aquaculture (Kestemont and Dabrowski, 1996). Although perch has been grown for centuries mixed with other cyprinids, representing between 2 and 5\% of fish production, its use in intensive crops is relatively recent (Mélard et al., 1995).

Therefore, our research was directed towards highlighting the action of phenols, ammonia, some pesticides (Talstar One, Tilt 250 EC, Roundup ${ }^{\circledR}$ and two heavy metals on some important haematological parameters (erythrocytes, leukocytes, blood glucose levels) in perch.

\section{MATERIALS AND METHODS}

The research was performed on perch - Perca fluviatilis Linnaeus, 1758, with an average weight of $32.2 \pm 3.25 \mathrm{~g}$. Fish adaptation to laboratory conditions was conducted for two weeks in glass aquariums with a capacity of 1001 , under natural photoperiodic conditions and the oxygen dissolved in water was not below $80 \%$ (by using water aeration devices) of the maximum possible at the respective temperature and pressure. Feeding during this period was "ad libitum" once a day,

http://www.natsci.upit.ro

* Corresponding author, E-mail address: ponepal_maria@yahoo.com 
at around 10; during the experiments fish were not fed to avoid the additional influence of the food factor, thus allowing a better interpretation and comparison of the results.

The lots that met the necessary criteria (less than 5\% mortality rate during the first week, and no mortality rate in the second week of acclimatization, if the mortality rate in the first week was between 5 and 10\% ) were divided into experimental samples (about 10 samples/experimental lot): lot Witness, lot I - heayy metals (I.1 and I.2 with $\mathrm{Cu} 0.001$ and $0.001 \mathrm{mg} / \mathrm{l}$ water; I.3 and I.4 with $\mathrm{Pb} 0.001$ and $0.01 \mathrm{mg} / \mathrm{l}$ water), lot II - pesticides (II.1 and II.2 with Talstar One 0.001 and 0.01 $\mathrm{ml} / 1$ water; II.3 and II.4 with Tilt $250 \mathrm{EC} 0.001$ and $0.01 \mathrm{ml} / \mathrm{l}$ water and II.5 and II.6 with Roundup 0.001 and $0.01 \mathrm{ml} / 1$ water, lot III with phenol (III.1 and III.2 with 0.001 and $0.01 \mathrm{mg} / \mathrm{l}$ water) and lot IV with ammonia (IV.1 and IV 2, with 0.001 and $0.01 \mathrm{mg} / \mathrm{l}$ water).

The observed concentrations were established after researching data from the literature on the toxicity of the pollutants monitored in different species of fish, followed by laboratory survival tests. It was also intended to use the same concentrations of different pollutants, in order to make a comparison between their toxic effects. The tests performed were semi-static conditions, with the "refreshing" of the solution every 24 hours.

For all experimental groups, survival was monitored daily, with dead specimens being periodically removed. Specimens that survived for 10 days were sacrificed (after prior chloroform anesthesia) to obtain the blood samples needed to determine the number of erythrocytes, leukocytes and blood glucose levels.

Each lot was a witness in itself, the oxygen consumption and the respiratory rate being established under standard conditions.

The number of red and white blood cells was determined using Thoma counting chambers, following the method described by Picos and Năstăsescu (1988) with blood from the caudal artery after two weeks of experiment. Blood glucose level was determined with the Accutrend device from caudal blood drop.

The results were interpreted statistically using SPSS 13.0 program for Windows, in accordance with the specialized studies.

\section{RESULTS AND DISCUSSIONS}

Haematological parameters reflect the condition of fish much faster than determining other parameters because they change extremely rapidly as environmental conditions change, which is why they are widely used to describe the health of fish.

Haematological and biochemical parameters can be used as standard laboratory tests to determine the effects of metabolic disorders caused by the action of xenobiotics (Masopust, 2000; Celik, 2004).

The effect of the test compounds on the number of erythrocytes in perch, after 10 days of exposure, is shown in Figure 1.

In all experimental variants with heavy metals, at the end of the experiments we found a significant reduction (for the variation threshold $\mathrm{p}<0.005$ ) of the average number of erythrocytes. The strongest effect, for both concentrations experienced - $0.0001 \mathrm{mg} / \mathrm{l}$ and $0.01 \mathrm{mg} / \mathrm{l}$ - was found in the lead variants (a reduction of $8.43 \%$ compared to the control group, in the case of the concentration of $0.001 \mathrm{mg} / 1$ and $47.86 \%$ at a concentration of $0.01 \mathrm{mg} / \mathrm{l}$ ). In the case of copper intoxicated perch, the reduction in the number of erythrocytes was by $5.84 \%$ at a concentration of $0.001 \mathrm{mg} / \mathrm{l}$ and by $40.47 \%$ at a concentration of $0.01 \mathrm{mg} / \mathrm{l}$.

http://www.natsci.upit.ro

* Corresponding author, E-mail address: ponepal_maria@yahoo.com 

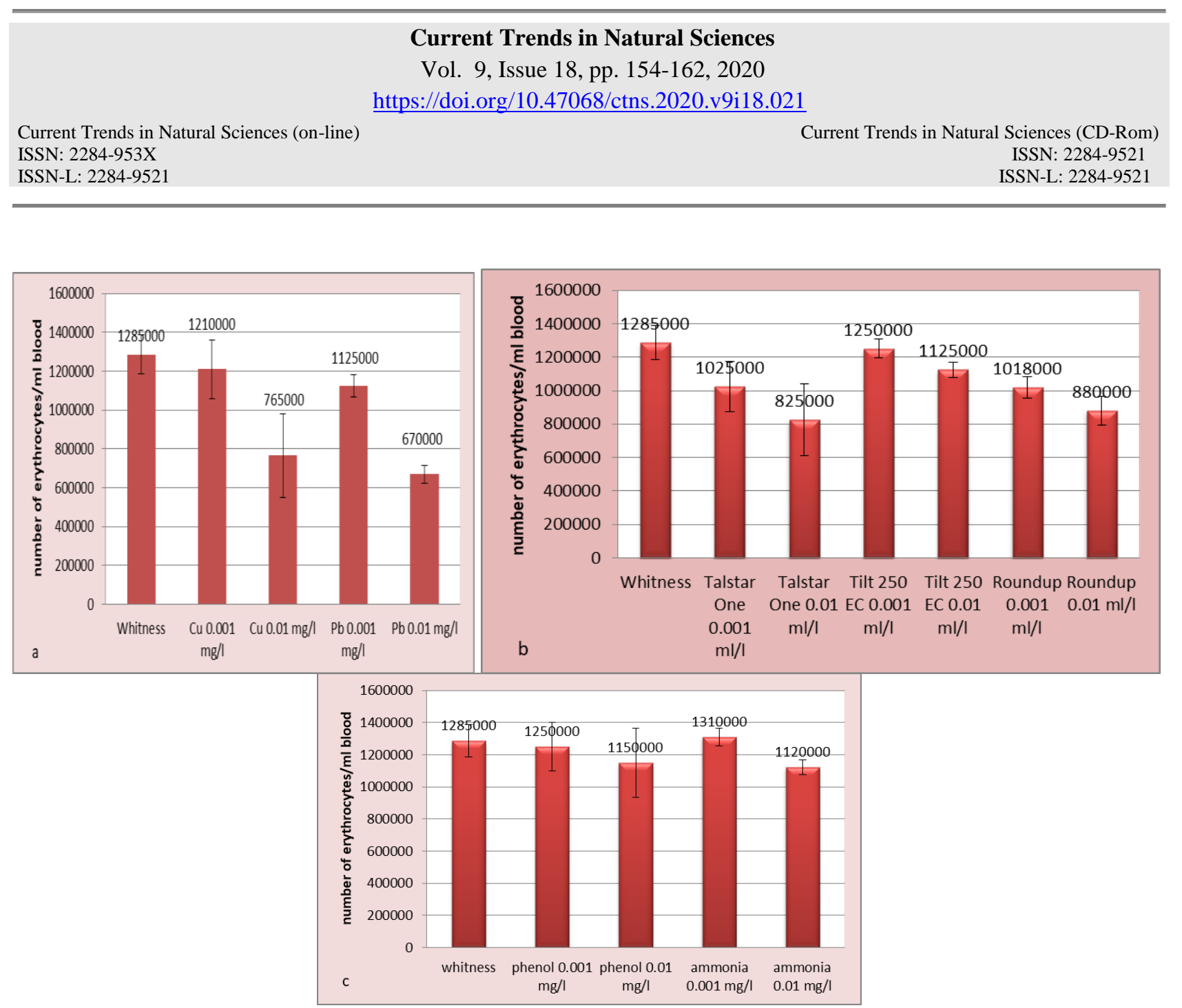

Figure 1. Mean erythrocyte count and standard deviation in perch after 10 days of exposure to toxic substances $a$ - heavy metals; $b$ - pesticides; $c$ - phenol and ammonia

Sublethal concentrations of lead induce haematological and neurological effects in fish, according to research of Hodson et al., 1984. Lead causes premature death of red blood cells and inhibits haemoglobin formation by inhibiting $\delta$-amino levulinic acid dehydrase. The result of these changes is the appearance of anaemia in case of exposure to high concentrations of lead, respectively compensatory effect of erythropoiesis at low concentrations (Hodson, 1976; Hodson et al., 1978).

Except in the variant in which the effect of the fungicide Tilt 250 EC in a concentration of 0.001 $\mathrm{ml} / \mathrm{l}$ water was followed, in the other cases, the 10 days of exposure to pesticides resulted in a significant decrease in the average number of erythrocytes. The strongest anaemia's were found in the case of the insecticide Talstar One, with reductions of $20.23 \%$ compared to the control at the concentration of $0.001 \mathrm{ml} / \mathrm{l}$ water and of $45.80 \%$ at the concentration of $0.01 \mathrm{ml} / \mathrm{l}$ water; we mention that, in the latter case, the survival within the group was only $20 \%$. We recorded similar results in Roundup poisoning, the weakest effect being for the Tilt fungicide.

Ponepal et al., 2010 reported, after 14 days of exposure of perch and oblates to the action of the insecticide Talstar One in a concentration of $0.000625 \mathrm{ml} / \mathrm{l}$, a decrease in the number of erythrocytes. The decrease in the number of erythrocytes in carp intoxicated with pyrethroid insecticides (permethrin and cypermethrin) was also found by Svobodova et al. (2003) and Doruncu and Girgin (2001), being attributed to haematopoiesis dysfunction.

http://www.natsci.upit.ro

* Corresponding author, E-mail address: ponepal_maria@yahoo.com 


\section{Current Trends in Natural Sciences}

Vol. 9, Issue 18, pp. 154-162, 2020

https://doi.org/10.47068/ctns.2020.v9i18.021

Current Trends in Natural Sciences (on-line)

ISSN: 2284-953X

Current Trends in Natural Sciences (CD-Rom)

ISSN: 2284-9521

ISSN-L: 2284-9521

ISSN-L: 2284-9521

Exposure to Talstar EC 10 at a concentration of $57.5 \mu \mathrm{g} 1-1$ had no effect on the number of erythrocytes in common carp (Cyprinus carpio), the values not being significantly different from those determined in the control group (Velisek et al., 2009). Anaemia following Roundup® (glyphosate active) intoxication has also been reported by Păunescu et al. in 2011 in Pelophylax ridibundus.

Both ammonia and phenol did not have significant effects on the average number of erythrocytes at the concentration of $0.001 \mathrm{mg} / \mathrm{l}$ water (toxic concentrations cited in the literature being much higher than those tested). At a concentration of $0.01 \mathrm{mg} / \mathrm{l}$ water, both substances produced a slight decrease in the number of erythrocytes (by $10.51 \%$ compared to the control of phenol and by $12.41 \%$ in the case of ammonia).

The effect of the test compounds on the number of leukocytes in perch, after 10 days of exposure, is shown in Figure 2.

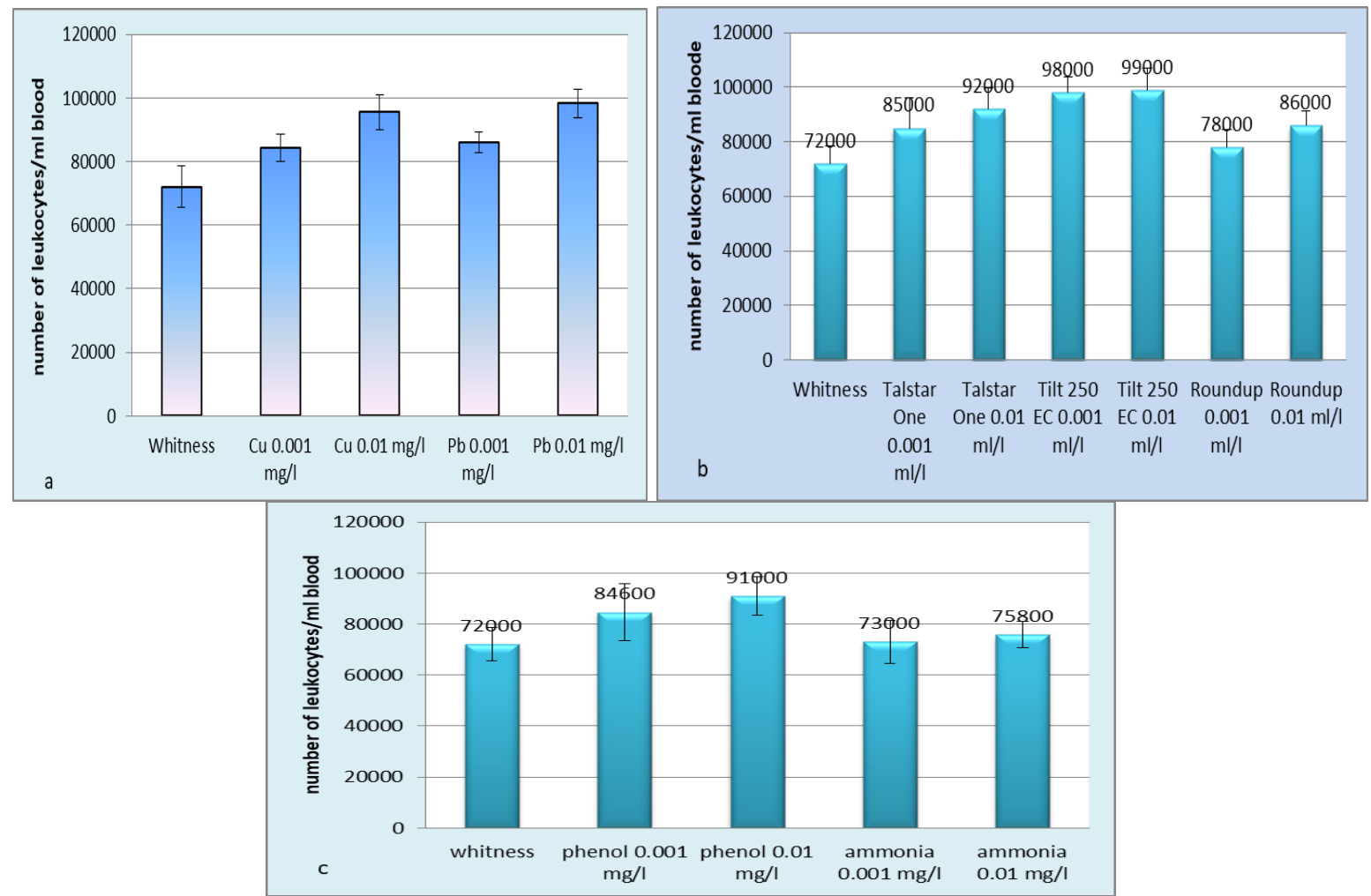

Figure 2. Mean leukocytes count and standard deviation in perch after 10 days of exposure to toxic substances $a$-heavy metals; $b$ - pesticides; $c$ - phenol and ammonia

Exposure for 10 days of perch to copper and lead, in concentrations of the two tested concentrations produced a significant increase in the average number of leukocytes, the effect being much more visible at a concentration of $0.01 \mathrm{mg} / \mathrm{l}$ water - by about $15 \%$ of the control group at a concentration of $0.001 \mathrm{mg} / \mathrm{l}$ water and by $30-35 \%$ at a concentration of $0.01 \mathrm{mg} / \mathrm{l}$. Regarding the evolution of this physiological parameter, there are no major differences between the two metals.

The average number of leukocytes in the pesticide variants increased significantly in comparison with the control values, the strongest effect being found in the Tilt variant (an increase of about

http://www.natsci.upit.ro

\footnotetext{
* Corresponding author, E-mail address: ponepal_maria@yahoo.com
} 


\section{Current Trends in Natural Sciences}

Vol. 9, Issue 18, pp. 154-162, 2020

https://doi.org/10.47068/ctns.2020.v9i18.021

Current Trends in Natural Sciences (on-line)

ISSN: 2284-953X

Current Trends in Natural Sciences (CD-Rom)

ISSN: 2284-9521

ISSN-L: 2284-9521

ISSN-L: 2284-9521

$35 \%$, without significant differences between the tested concentrations). The weakest stimulant effect on the number of leukocytes was found in the variants with Roundup herbicide, in which the increase was $8.33 \%$ at a concentration of $0.001 \mathrm{ml} / 1$ and $19.44 \%$ at a concentration of $0.01 \mathrm{ml} / 1$ water.

Phenol and ammonia cause an increase in the average number of leukocytes in the case of perch intoxications with a concentration of $0.01 \mathrm{mg} / \mathrm{l}$ water in these products (by $26.38 \%$ in the case of phenol and only by $5.27 \%$ in ammonia. At a concentration of $0.001 \mathrm{mg} / \mathrm{l}$ water, ammonia has no significant effects on this parameter, while phenol produces a $17.5 \%$ increase in the number of leukocytes.

Physiological indicators of stress, such as plasma cortisol and glucose levels, are frequently used to assess whether fish are stressed and whether the hypothalamic-pituitary-interrenal system is functioning properly. Due to the fact that fish live in a low-carbohydrate but high-protein environment, they can use lipids and proteins more efficiently than carbohydrates as an energy source (Matty and Lone, 1985). The importance of glucose as an energy source in fish is quite limited (Stone, 2003).

Copper and lead, in concentrations of $0.001 \mathrm{mg} / \mathrm{l}$ water, produce insignificant increases (on average by $5 \%$ compared to the control values) in perch after 10 days of intoxication - figure 3 . At a concentration 10 times higher, the hyperglycaemic effect is very strong (with $65.11 \%$ for copper and $27.9 \%$ for lead, respectively).
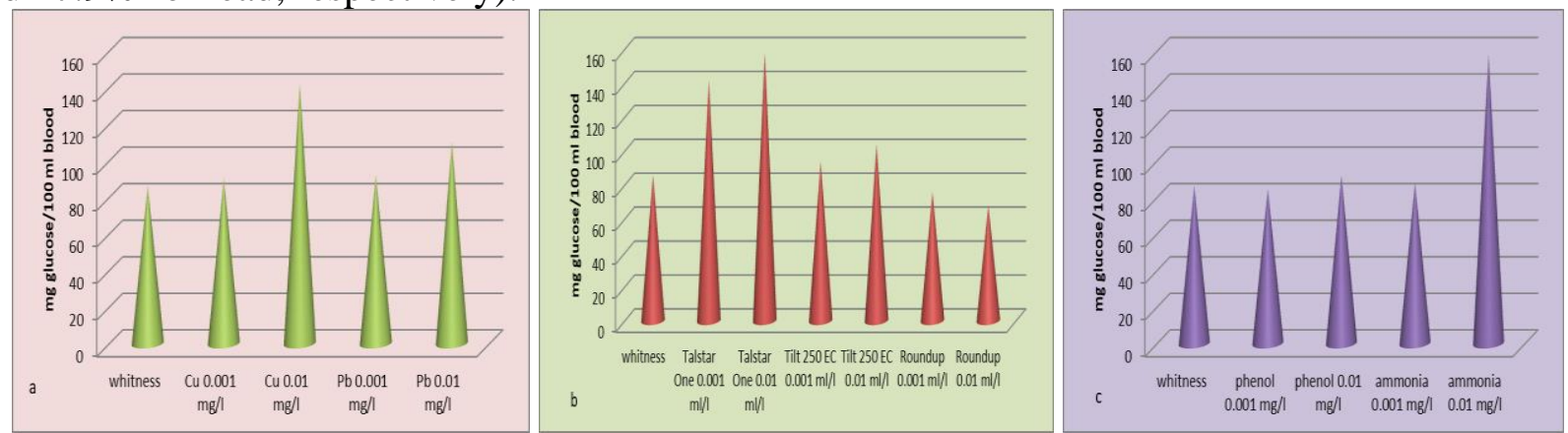

Figure 3. Mean blood glucose values in perch after 10 days of exposure to toxic substances $a$ - heavy metals; $b$ - pesticides; $c$ - phenol and ammonia

Kavidha and Muthulingam (2014) report a decrease in glycogen levels in the gills and kidneys of carp, following exposure for 10, 20, and 30 days to sublethal $\mathrm{Pb}$ concentrations. A strong hyperglycaemic effect was also observed in fish intoxicated with other metals $(\mathrm{Cd}, \mathrm{Cu})$ Donaldson, 1981.

Talstar One insecticide and Tilt 250 EC fungicide, in both tested concentrations, produce an increase in blood glucose levels in perch after 10 days of exposure - by 65.11 and $83.72 \%$ Talstar respectively and by 9.3 and 20.93\% Tilt, respectively. However, Roundup herbicide had a hypoglycaemic effect in both concentrations tested (recording reductions of 11.63 and 20.94\%, respectively, compared to the control values).

Păunescu et al. in 2011 found a decrease in blood glucose by $18.18 \%$ for frogs (Pelophylax ridibundus) treated with Roundup ${ }^{\circledR}$ herbicide and kept at $4-6^{\circ} \mathrm{C}$, and by $34.78 \%$ compared to the control for animals treated with the same concentration of toxic but kept at $22-24^{\circ} \mathrm{C}$. Velisek et al. (2009), examining the biochemical profile of carp after 96 hours of exposure to bifentrin at a

http://www.natsci.upit.ro

* Corresponding author, E-mail address: ponepal_maria@yahoo.com 


\section{Current Trends in Natural Sciences}

Vol. 9, Issue 18, pp. 154-162, 2020

https://doi.org/10.47068/ctns.2020.v9i18.021

Current Trends in Natural Sciences (on-line)

ISSN: 2284-953X

Current Trends in Natural Sciences (CD-Rom)

ISSN: 2284-9521

ISSN-L: 2284-9521

ISSN-L: 2284-9521

concentration of $57.5 \mu \mathrm{g} 1-1$, also found significant increases in glucose levels. Histological examination revealed hepatocyte degeneration. An increase in blood glucose was recorded in trout and crucian by Velisek et al., (2009) in response to metabolic stress induced by the action of the insecticide Talstar 10 EC.

At a concentration of $0.001 \mathrm{mg} / \mathrm{l}$ water, phenol and ammonia do not produce significant changes in blood glucose levels after 10 days of immersion of fish in the respective solutions. At a concentration of $0.01 \mathrm{mg} / \mathrm{l}$ water, phenol causes a slight increase in blood sugar levels, while ammonia has a strong hyperglycaemic effect (an increase of $83.72 \%$ compared to the control), the effect being similar to that found in Talstar One poisoning.

A 1984 study by Gupta and Srivastava on Heteropneustes fossilis showed a change in carbohydrate metabolism following phenol exposure (fish were poisoned with phenol at $26 \mathrm{mg} / \mathrm{l}-0.8$ of LC5096 h) - hyperglycaemia after 3, 6 and 12 hours after exposure, a significant increase in the amount of pyruvate in the blood after 3 hours after exposure.

Survival rates for the mounted experimental variants are shown in Table I.

Table 1. Percentage of survivors in the experimental variants performed

\begin{tabular}{|c|c|c|c|c|c|c|c|}
\hline & W & $24 \mathrm{~h}$ & $48 \mathrm{~h}$ & $72 \mathrm{~h}$ & $96 \mathrm{~h}$ & 7 days & 10 days \\
\hline Whitness & 100 & 100 & 100 & 100 & 100 & 100 & 100 \\
\hline $\mathrm{Cu} 0.001 \mathrm{mg} / \mathrm{l}$ & 100 & 100 & 100 & 100 & 100 & 100 & 100 \\
\hline $\mathrm{Cu} 0.01$ mg/l & 100 & 100 & 100 & 100 & 100 & 1000 & 100 \\
\hline $\mathrm{Pb} 0.001 \mathrm{mg} / \mathrm{l}$ & 100 & 100 & 100 & 100 & 100 & 100 & 100 \\
\hline $\mathrm{Pb} 0.01 \mathrm{mg} / \mathrm{l}$ & 100 & 100 & 100 & 100 & 100 & 100 & 90 \\
\hline Talstar One $0.001 \mathrm{ml} / \mathrm{l}$ & 100 & 100 & 100 & 90 & 90 & 80 & 80 \\
\hline Talstar One $0.01 \mathrm{ml} / \mathrm{l}$ & 100 & 90 & 90 & 80 & 60 & 50 & 20 \\
\hline Tilt $0.001 \mathrm{ml} / 1$ & 100 & 100 & 100 & 100 & 100 & 100 & 100 \\
\hline Tilt $0.01 \mathrm{ml} / \mathrm{l}$ & 100 & 100 & 100 & 90 & 90 & 80 & 80 \\
\hline Roundup $0.001 \mathrm{ml} / \mathrm{l}$ & 100 & 100 & 100 & 100 & 100 & 100 & 90 \\
\hline Roundup $0.01 \mathrm{ml} / \mathrm{l}$ & 100 & 100 & 80 & 80 & 70 & 70 & 70 \\
\hline Phenol 0.001 mg/l & 100 & 100 & 100 & 100 & 100 & 100 & 100 \\
\hline Phenol 0.01 mg/l & 100 & 100 & 100 & 100 & 100 & 100 & 100 \\
\hline Ammonia $0.001 \mathrm{mg} / \mathrm{l}$ & 100 & 100 & 100 & 100 & 100 & 100 & 100 \\
\hline Ammonia $0.01 \mathrm{mg} / \mathrm{l}$ & 100 & 100 & 100 & 100 & 100 & 90 & 90 \\
\hline
\end{tabular}

In the tested concentrations, bifentrin causes irritability, muscle tremors, convulsions, ataxia and even death of fish. Paralysis is preceded by muscle spasms due to hyperactivity of the nerve endings, and before the onset of paralysis there is a decrease in the intensity of swimming. The symptoms found by other authors in case of exposure of fish to the action of pyrethroid pesticides are similar to those found: swimming near the water surface, hyperactivity, loss of balance, increased secretion of gill mucus, etc. (Velisek et al., 2009).

The researches carried out by Mălăcea et al., 1964 (cited from Mălăcea, 1969) highlighted the neurotoxic and irritating action of phenols and determined the TLm values of $96 \mathrm{~h}$ for phenol and hydroquinone: for $20 \mathrm{mg} / \mathrm{l}$ and 0.1 , respectively, for Phoxinus phoxinus. Marinescu's experiments with ammonium sulphate on fish and daphnia (1972) had the following results: TLm 96 hours for daphnia was $160 \mathrm{mg} / \mathrm{l}$ and for carp $200 \mathrm{mg} / \mathrm{l}$.

Regarding the survival of fish in toxic ammonia solutions, the amount of dissolved oxygen in the water is very important. Thus, at $1.4 \mathrm{mg} \mathrm{NH}_{3} / 1$ the survival of the trout - depending on the oxygen

http://www.natsci.upit.ro

* Corresponding author, E-mail address: ponepal_maria@yahoo.com 
in the water - is 14 hours at $95 \%$ oxygen saturation, 1.3 hours at $60 \%$ oxygen saturation and 35 minutes at 30\% saturation in oxygen (Allan, 1955 - quoted from Mălăcea, 1969).

\section{CONCLUSIONS}

Copper and lead, at a concentration of $0.001 \mathrm{mg} / \mathrm{l}$ water, do not produce significant changes in erythrocytes and blood glucose. At a concentration of $0.01 \mathrm{mg} / \mathrm{l}$ water, after 10 days of intoxication, perch have a significant reduction in the number of erythrocytes - a stronger effect in the lead variant and an increase in blood glucose values, a more pronounced effect in the copper variant. The number of leukocytes increased after exposure for 10 days of perch to the two heavy metals, a more pronounced effect for the concentration of $0.01 \mathrm{mg} / \mathrm{l}$, without significant differences between the two metals.

At a concentration of $0.01 \mathrm{ml} / \mathrm{l}$ water, the three investigated pesticides - Talstar One, Tilt $250 \mathrm{EC}$ and Roundup - reduce the number of erythrocytes in perch, after a 10-day exposure, the most severe anaemia occurring in the version with Talstar One, where survival was only $20 \%$ of the lot. At a concentration 10 times lower, the reducing effect was found only for Talstar One and Roundup. The three pesticides tested, in the two investigated concentrations, produced a significant increase in the number of leukocytes in perch. Blood sugar, the energy substrate of the various reactions, although not as important as in mammals, increases significantly in the variants made with Talstar One and Tilt $250 \mathrm{EC}$ at a concentration of $0.01 \mathrm{ml} / \mathrm{l}$, the insecticide having a hyperglycaemic effect and a concentration of $0.001 \mathrm{ml} / \mathrm{l}$ water. Roundup herbicide has a hypoglycaemic effect in both concentrations tested.

Phenol does not produce significant effects on the investigated parameters, except for the increase in the number of leukocytes, its toxic effects occurring, as it appears from the literature, at higher concentrations. Ammonia at a concentration of $0.01 \mathrm{mg} / \mathrm{l}$, produces a reduction in the number of erythrocytes, with insignificant effects on the number of leukocytes. At a concentration of 0.01 $\mathrm{mg} / \mathrm{l}$, a very strong hyperglycaemic effect was found - similar to the insecticide variant, of over $200 \%$ compared to the control.

The survival of perch in the mounted experimental variants was over $70 \%$, except for the variant with the insecticide Talstar One in a concentration of $0.01 \mathrm{ml} / 1$ water, when a mortality of $80 \%$ was registered after the 10 days of exposure. The main behavioural changes observed during intoxication, especially in the first days after exposure: irritability, muscle tremors, motor incoordination, convulsions, ataxia and even death of fish.

As it appears from our own research and from the specialized literature, the decrease of erythrocyte values, the increase of leukocyte number and glycaemia values can be considered haematological biomarkers in the intoxication of perch.

\section{REFERENCES}

Castillo, L.E., Ruepert, C., Solis, E. (2000). Pesticide residues in the aquatic environment of banana plantation areas in the north zone of Costa Rica. Environ. Toxicol. Chem. 19, 1942-1950.

Celik, E.S. (2004). Blood chemistry (electrolytes, lipoproteins and enzymes) values of black scorpion fish (Scorpaena porcus ) in the Dardanelles. Turkey J. Biol. Sci., 4(6), 716-719.

Depledge, M.H. and Rainbow, P.S. (1990). Models of regulation and accumulation of trace metals in marine invertebrates. Comp. Biochem.Physiol., C 97, 1-7.

Donaldson, E.M. (1981). The pituitary-interrenal axis as indicator of stress in fish. In: A. D. Pickering (ed.), Stress and fish. Academic Press, London.

http://www.natsci.upit.ro

* Corresponding author, E-mail address: ponepal_maria@yahoo.com 


\section{Current Trends in Natural Sciences}

Vol. 9, Issue 18, pp. 154-162, 2020

https://doi.org/10.47068/ctns.2020.v9i18.021

Current Trends in Natural Sciences (on-line)

ISSN: 2284-953X

Current Trends in Natural Sciences (CD-Rom)

ISSN: 2284-9521

ISSN-L: 2284-9521

ISSN-L: 2284-9521

Dorucu, M., Girgin, A. (2001). The effects of cypermethrin on some haematological parameters of Cyprinus carpio. Aquaculture International. 9: 183-187.

Eisler, R. (1988). Lead hazards to fish, wildlife, and invertebrates: a synoptic review. U.S. Fish Wildl. Serv. Biol. Rep. 85(1.14).

Gupta, A.B., Srivastava, A.K. (1984). Phenol induced changes in the carbohydrate metabolism of the Indian catfish Heteropneustes fossilis, Environmental Biology of Fishes Vol . 10, No . 3, pp . 221-224.

Hansson, T., Hansen, W., Tjärnlund, U., Balk, L., Bengtsson, B.E. (2014). Biomarker investigations in adult female perch (Perca fluviatilis) from industrialised areas in northern Sweden in 2003, Arch Environ Contam Toxicol, 66:237-247, DOI 10.1007/s00244-013-9974-5.

Hodson, P.V. (1976). $\delta$-amino levulinic acid dehydratase activity of fish blood as an indicator of a harmful exposure to lead. J. Fish. Res. Board Can., 33, 268-271.

Hodson, P.V., Blunt, B.R., Spry, D. J. and Austen, K. (1977). Evaluation of erythrocyte $\delta$-amino levulinic acid dehydratase activity as a short-term indicator in fish of a harmful exposure to lead. J. Fish. Res. Board Can., 34, 501-508.

Hodson, P.V., Blunt, B.R. and Spry, D.J. (1978). PH induced changes in blood lead of lead-exposed rainbow trout (Salmo gairdneri). J. Fish. Res. Board Can., 35, 437-445.

Hodson, P.V., Whittle, D.M., Wong, P.T.S., Borgmann, U., Thomas, R.L., Chau, Y.K., Nriagu, J.O. and Hallet, D.J. (1984): Lead contamination of the Great Lakes and its potential effects on aquatic biota. In: J. O. Nriagu \& M. S. Simmons (eds.), Toxic contaminants in the Great Lakes. John Wiley and Sons, Indianapolis, In.

Horne, M. T. and W. A. Dunson (1995): Effects of low pH, metals, and water hardness on larval amphibians. Archives of Environmental Contamination and Toxicology. 29, 500-505.

Kavidha, K. and Muthulingam, M. (2014). Lead acetate induced glycogen level alterations in gill and kidney tissues of freshwater fish Cyprinus carpio (Linn.). Int J Mod Res Rev 2, 17-521.

Kestemont, P., Dobrowski, K. (1996). Recent Advances in the Aquaculture of Percid Fish, J.Appl. Ichtyol. 12 (3-4), 137-200.

Mălăcea, I. (1969). Biologia apelor impurificate : Bazele biologice ale protecţiei apelor.[ Biology of impurified waters : Biological basis of water protection]. Bucureşti : Editura Academiei Republicii Socialiste România, 248 p.

Marinescu, A.G. (2000). Fiziologia metabolismului animal [Physiology of animal metabolism], Ed. Universităţii Piteşti, pp.217.

Marinescu, Al.G. (1972). Influenţa factorilor endo şi exogeni aupra metabolismului energetic al peştilor [Influence of endo and exogenous factors after fish energy metabolism], Ref. Tez. Doct. Cluj-Napoca.

Masopust, J. (2000). Clinical Biochemistry (in Czech). Karolinum, Praha. 832 pp.

Matty, A. I., Lone, K.P. (1985). Hormonal control of protein deposition. In: Nutrition and Feeding in Fish (Cowey, C. B., Mackie, A. M. \& Bell, I. G., eds.|, pp. 147-167, Academic Press, London.

Mélard, C., Baras, E., Kestemont, P. (1995). Preliminary results of European perch Perca fluviatilis intensive rearing trials: effects of temperature and size grading on growth. Bull. Fr. Pêch. Pisc. 336, 19-27.

Mokry, L.E., Hoagland, K.D. (1989). Acute toxicities of five synthetic pyrethroid insecticides to Daphnia magna and Ceriodaphnia dubia. Environmental Toxicology and Chemistry 9, 1045-1051.

Păunescu A., Ponepal, M.C. (2011). Effect of Roundup ${ }^{\circledR}$ herbicide on physiological indices in marsh frog (Pelophylax ridibundus). Scientific Papers, UASVM Bucharest, Series A, Vol. LIV, 269-274.

Picoş, C.A., Năstăsescu, Gh. (1988). Lucrări practice de fiziologie animală [Practical work of animal physiology], Tipografia Universităţii din Bucureşti, 107, 122-123, 192-195.

Ponepal, M.C., Păunescu, A., Marinescu, Al.G., Drăghici, O. (2010). Research on the changes of some physiological parameters in several fish species under the action of the Talstar insecticide. Analele Universităţii din Oradea, Fascicula Biologie. Tom. XVII (1), 175-179.

Stone, D.A.J. (2003). Dietary carbohydrate utilization by fish. Rev Fish Sci 11:337-369, doi:10.1080/10641260390260884.

Svobodova, Z., Luskova, V., Drastichova, J., Svoboda, M., Zlabek, V. (2003). Effect of deltamethrin on haematological indices of common carp (Cyprinus carpio L.). Acta Veterinaria Brno. 72, 79-85.

U.S. Environmental Protection Agency. (1992). Pesticide tolerance for glyphosate. Fed. Reg. 57, 8739-8740.

Velisek, J., Svobodova, Ć.Z., Machova, Ć.J. (2009). Effects of bifenthrin on some haematological, biochemical and histopathological parameters of common carp (Cyprinus carpio L.). Fish Physiol Biochem. 35, 583-590.

http://www.natsci.upit.ro

* Corresponding author, E-mail address: ponepal_maria@yahoo.com 